\title{
The Councils of the Archipelagoes in the basic law of French Polynesia - M. Vernaudon C. Territoire de la Polynesie Francaise - decision of the Administrative Tribunal of Papeete of 18 May 1994
} A Moyrand" and Y-L Sage**

The judgment of the Administrative Tribunal of Papeete of 18 May 1994, concerning the illegality of the tariffs applicable to sea transport services, is destined to cause an upset in the constitutional landscape of French Polynesia. The law of 12 July 1990, which amended the law of 6 September 1984 on the status of French Polynesia, had inserted an article 89 bis which provided for the creation of councils of the archipelagoes which would have to be necessarily consulted in two areas: maritime transport and development plans, and the general economic plan ${ }^{1}$. The establishment of these councils in the five archipelagoes of French Polynesia which was so much desired by Mr Emile Vernaudon when he was a member of the coalition majority, never happened because shortly after the vote on this reform by the national legislature, Mr Gaston Flosse, as the result of the territorial elections of March 1991, was again placed at the head of the territorial government. This latter had never made any secret of his opposition to the reform of July 1990 even though it

* Maître de Conférences, Université Française du Pacifique, Avocat (Papeete Bar).

** Maître de Conférences, Université Française du Pacifique, Honorary Fellow in Law, Victoria University of Wellington. Avocat (Papeete Bar).

1 Title 2 of the basic law is headed Councils of the Archipelagos has one article (89B) which states as follows: "There is established in the Windward Isles, the Leeward Isles, the Australes, the Tuamotu, and Gambier, and the Marquesas, a council for the archipelago made up of members of the territorial assembly and the elected mayors of these islands. The President of each council will be elected from within the council each year.

These councils must be consulted by the president of the government of the territory on development plans and the contracts for the plan, and the general measures taken for their application as well as about maritime and air transport that concern them.

In relation to economic, social or cultural matters which concern the archipelago, notably educational matters, employment, and professional training, the development of the local languages and cultures, the councils of the archipelagos will give advice either on their own initiative or in response to a request from the president of the government of the territory, the president of the territorial assembly or from the high commissioner.

The President of the government of the territory can consult the councils on the individual allocation of aid to local enterprises.

The President of the government of the territory or his representative, the high commissioner or his representative may be present of right at sittings of the councils of the archipelagos. They each have a right to speak at their request.

The territorial assembly will by decision elaborate the detail of the organisation and the operation of these councils." 
constituted only a very limited weakening of the central territorial power. The system in fact is far from the New Caledonian pattern which provides for true decentralisation of territorial power.

In order to force the administration out of its inactivity Vernaudon, now in the opposition ${ }^{2}$, challenged the legality of a government decision which should have been taken after consultation with the councils of the archipelagoes. It is a basic principle in administrative law that an official document which could only have become formal after receiving the advice of an institution with which consultation is required, is tainted with illegality if the writer has failed to seek the advice required and even if that advice would have been within the category of non-binding advice or of binding advice. A consistent line of case law has decided that in such a case the government has neglected a "substantial formality" 3 unless the administrative authority can show the existence of circumstances which made consultation impossible. In that case, there is room for the operation of the theory which relates to "impossible formalities" and which authorises the government to formalise documents without having received the advice of the body with which consultation was required.

The administrative court had therefore to decide, in the instant case, whether the territorial government could justify its failure to consult the councils of the archipelago's by reasons for which it was not to blame.

It is clear that the government can dispense with the need to seek advice from a consultative body, and therefore benefit from the principle of impossible formalities, if this failure results first of all from exceptional circumstances. In the present case, the inactivity of the government for more than three years could not in any way be explained by such circumstances. The government was also unable to rely on any material hindrance such as could have resulted from the bad faith of the members of the councils of the archipelagoes. Things done by members of a council (such as a failure to sit or to give advice, block

2 It is to be noted that the administrative tribunal of Papeete accepted the petition of Mr Vernaudon on the basis of his "standing as a user of inter-island maritime transport". The first instance judge held "that on this basis at least he had a sufficient interest". But Mr Vernaudon could also have based his standing on his membership of an organisation which had not been consulted since, as mayor and territorial council, he was a member as of right of the Council of the Archipelago of the Windward Isles. In fact, a line of cases recognises in the members of an administrative organisation the capacity to act against official decisions which abuse the role conferred on that organisation. (CE 13 décembre 1912, Bobjean, Benaitreau et autres, Rec p 1207; CE sect 9 décembre 1938, Sieur Ganne, Rec p 923) or taken without proper notice fromthe organisation (CE 30 avril 1926, Sieur Suran, Rec p 439; CE 4 décembre 1935, Canat, Rec p 1135; CE sect 26 octobre 1956, Demoiselle Cavalier et autres, Rec p 387; CE 25 janvier 1963, Lemaresquier, D p 334, conclusions Kahn; CE 30 mars 1977, Secrétaire d'État aux Universités c/ Carreau, Rec p 170).

3 Eg CE 17 mai 1968, Sieur Herrenschmidt et syndicat autonome du personnel de l'expansion économique à l'étranger, AJDA 1968, p 644, note VS. 
resignation, etc.) with the object of obstructing the operation of the institution ${ }^{4}$ would amount to such a hindrance, and therefore be a valid excuse for the government to fail to consult the council. In this case, the councils had not been constituted or, more accurately, no decision of the Territorial Assembly had been taken to set out the details of the organisation and functioning of the councils.

A final exception to the principle of consultation is the hypothesis of "a legal obstacle". And it was on this basis that the government tried to take advantage of the theory of impossible formalities. In nullifying the edict in question, the Administrative Tribunal stated clearly that the argument based on a legal impossibility was not sustained since it was the territorial authorities themselves which created the impossibility of proceeding to consult with the councils of the archipelagoes. Therefore, since it had failed to establish the councils of the archipelagoes, the government, in fixing the tariffs applicable for marine transport, had not made it possible for the decision to be transmitted to the councils for their advice, and this failure nullified the procedure for the promulgation of this tariff. If, in deciding this way, the administrative tribunal made a decision which appears beyond criticism, it is nevertheless true that it could have reached the same result by adopting a simpler line of reasoning. That is to say, a line of reasoning which avoided the need to check whether the conditions for the theory of impossible formalities were or were not fulfilled. It would have been possible to have the tariff annulled (because it was set without consultation with the councils of the archipelagoes) if the judge had stated that the provisions of the basic law relative to these institutions were immediately applicable provisions because they are sufficiently precise, not withstanding the failure of the Territorial Assembly to make the decisions which were necessary for the organisation and operation of these councils. On this basis, the tariff would be tainted with illegality not because of the failure to create the councils of the archipelagos, but because of the failure to consult with them.

\section{Failure to legislate}

When a law provides that there should be compulsory consultation with a new institution, it is possible to consider that the impossibility which the government faced to establish this institution, because it is not within the jurisdiction of the administrative

4 CE 23 janvier 1931, Rondeau, Rec p 91; CE sect 3 mars 1939, Delmas, Dupuis et autres, Rec p 135; CE 1er décembre 1943, Chambre syndicale de l'affichage de France, Rec p 276; CE sect 12 octobre 1956, Baillet, Rec $\mathrm{p}$ 356, D 1956, p 664, concl Long; CE 26 octobre 1956, Henriot, RDP 1957, p 159; CE 16 novembre 1956, Pénicault, Rec p 432; CE 2 novembre 1960, Cassane, Rec p 581; CE sect 24 avril 1964, Delahaye, Rec p 243; CE 17 mars 1965, Ménasse, Rec p 179; CE 27 mai 1966, Carron, Rec p 367; CE 27 octobre 1966, Carron, Rec p 367; CE 14 novembre 1975, Syndicat national de l'enseignement supérieur, Rec p 571, Concl J Théry. 
authority to set such a formal document by decree, constitutes a legal obstacle ${ }^{5}$, and therefore a reason for failure to consult with that institution. This is what the Council of State, the highest court for administrative law matters, has decided in respect of nonconsultation with an institution whose establishment would require the intervention of the legislature ${ }^{6}$.

That is not the position if the creation of the institution is to flow from a regulatory act, because in that case the impossibility of consulting the institution would result from administration inaction. After a reasonable period (substantially passed in the instant case) the fact that the legislation was not immediately applicable because the necessary operational requirements had still to be fixed would not provide an excuse, since the failure of the government would be interpreted as a deliberate decision to refuse to perform a "duty to act"7. Nor is there a legal impossibility which justifies a failure to consult with an institution when there has been no reorganisation of this matter as made necessary by reforms of general structures. All of which confirms the responsibility of administrative authorities to adapt the composition of the institutions with which consultation is obligatory ${ }^{8}$ to the existing state of the law. In surveying this case law, Auby and Drago are of the opinion that the administrative court interprets this type of legal impossibility "in a restrictive manner"9. One must however, in view of the decision in Syndicat inter-comunal à vocation unique de Boe-Le-passage, federation nationale des syndicats de producteurs autonomes d'electricité ${ }^{10}$ modify this opinion. In fact, the highest administrative tribunal has applied the theory of "impossible formalities" to the government even when the failure to consult with a consultative committee could have been surmounted because since the entry into force of the 1958 constitution, the regulatory power to reorganise that committee was within the jurisdiction of the government ${ }^{11}$.

5 See examples given in Raymond Odent, Contentieux administratif fascicule V, Les cours de droit, 1976-1981, p 1900 et 1901.

6 CE 30 octobre 1959, Commune de Tignes et Epoux Reymond, Rec p 558.

7 Concl. Daël sur CE 25 novembre 1992, Syndicat intercommunal à vocation unique de Boe-Le-Passage, Fédération nationale des syndicats de producteurs autonomes d'électricité, CJEG 1993, p 234.

8 CE sect 1er juillet 1966, Société d'exploitation de la clinique du Rech et autres, Rec p 129; CE 16 janvier 1970, CGT, Rec p 22; CE sect 21 juin 1974, Seprim, Rec p 354, AJDA 1974, p 547, chron Franc et Boyon p 533; CE 27 juin 1990, Commune de Saint-Germain sur Morin", Rec p 170.

9 Traité de contentieux administratif, tome 2 LGDJ, 1984, p 320, n 1197.

10 CE, 25 novembre 1992.

11 In order to justify this position, the Commissioner for the government stated that it would not be possible to "impose on the regulatory power the adapt provisions in a legislative form which before the Constitution of 1958 had been inapplicable for many years as a result of the inaction of the legislature. See above p 234. 
In the case under discussion, "the duty to act" by the territorial authorities was presented with a novel twist. The basic law in fact gave the responsibility of fixing the details of the application of article 89B to the Territorial Assembly. Because of this, the failure to consult the Councils of the Archipelagoes could not be blamed on the territorial government since only a decision of the Territorial legislator was able to fix the detail of the organisation and operation of these councils ${ }^{12}$. On the institutional level, the territorial government was placed in the same situation as the national government which cannot be blamed for non-consultation with an institution whose establishment is the prerogative of the national legislator.

In order to nullify the tariff in question, the administrative court used article 24 of the basic law of 1984, which sets out the powers of the territorial government. This article specifies that the Council of Ministers "decides the matters that will be submitted to the Territorial Assembly for decision". Also, noting that the territorial government had never submitted a proposal for decision which related to the organisation and operation of the Councils of the Archipelagoes to the Territorial Assembly, the Administrative Tribunal of Papeete held that this omission tainted with illegality the decree which fixed the maximum tariffs for freight and passengers on sea transport in the Territory of French Polynesia. If the situation of the territorial government is compared with that of the national government, it can be noted that the same power belongs to the latter, since article 39 of the Constitution allows the government to present a Bill to the legislature for the establishment of the institutions whose failure to consult is pleaded by the petitioners.

However, if it is possible to compare the operation of the constitutional systems of the State and the Territory, it must not be forgotten that the legal nature of the rules made by the one and the other are different. Even when an institution of an overseas territory performs an action which is materially of a legislative nature - which is possible because article 74 of the Constitution permits a derogation from the division of powers established by articles 34 and 37 - it remains formally an administrative action. A judge who cannot force the national legislature out of inactivity when the Parliament refuses to take the steps necessary for the application of a piece of law, can on the other hand, by various means, censure the inactivity of any administrative authority even when this latter is a deliberative assembly whose members have been elected by universal suffrage.

12 But this circumstance, according to the administrative case law, could not be construed as a "legal impossibility". Indeed, when a statute empowers the deliberative assemblies of overseas territories to elaborate on some of its provisions but sets as a prior requirement a decree to define the conditions for the operation of the legislation, the non-promulgation of this regulatory law although not attributable to the decentralised institutions, deprives the latter of their power to enforce the statute: CE Avis, 20 March 1992, Prefect of Calvados, REC., p124. 
Thus in the present case, the annulling of a formal decision taken without consultation with an institution which must obligatorily be consulted, provides a first approach. Another approach would have been to annul the refusal by the relevant administrative authorities to participate in the preparation for the legislature of a proposal which concerned the organisation and operation of the Councils of the Archipelagos ${ }^{13}$. It is possible also to envisage delictual liability of the territorial authorities but the requirements that a loss be sustained would have been difficult to fulfil ${ }^{14}$. Such action would enable indirect pressure to be placed on the administrative authorities.

\section{Failure to consult}

In principle, when the coming into force of a piece of legislation is subordinated by virtue of its own provisions to the promulgation of laws which must provide for its application, the government acts illegally if it prematurely applies a piece of legislation, that is to say before the appearance of the application text ${ }^{15}$. The administrative authorities must therefore refuse to apply the piece of legislation so long as the rules for its application, which have expressly to be provided, have not been promulgated. ${ }^{16}$ The situation is otherwise when the legislative provisions are sufficient in themselves to be applied. In this case any argument of the government which relied on the fact that the text for the application of the law had not been promulgated would be if founded. Therefore, if the promulgation of rules for the application of the law is not necessary for the latter to come into force immediately, the government acts illegally if it fails to apply that law ${ }^{17}$.

In order to decide if the government has to apply a legal text without waiting for the promulgation of the measures which will establish the conditions of its application, an administrative court must decide whether the text is sufficiently "clear and precise ${ }^{\prime 18}$. The case law mostly admits the immediate application of statutes and decrees despite the nonpromulgation of the texts which provide for the means of the operation of these laws. It is only in the situation where these latter are absolutely indispensable or would render the

13 In this case, it appears that the prior request can be addressed to the President of the government of the Territory or to the President of the Territorial Assembly.

14 On this point, see Jean Marie Breton. "L'obligation pour l'administration d'exercer son pouvoir réglementaire d'exécution des lois. A propos de quelques décisions récentes du juge administratif', R.D.P. 1993, p 1749-1773.

15 CE 30 avril 1931, Sieur Philip, Rec. p 455; CE 15 juillet 1931, Sieur Etienne, Rec. p. 766; CE 25 mai 1988 , Mme Angoujard, Rec. T., p 604; CE 27 juin 1990, Commune de Saint-Germain sur Morin, op. cit.; CAA de Lyon, 1er octobre 1991, Assistance publique de Marseille c/ Mme Plaza, Rec. T., p 689.

16 CE 9 novembre 1988, Mme Delbru, Rec. T., p 604; CE 29 juin 1990, Ogire, Rec. T., p 566.

17 CE sect. 23 mai 1958, Ministre de l'Education nationale c/ sieur Weber, Rec. p 293; CE 26 février 1964, Ministre des finances et des affaires économiques c/ Sté des établ. Millo-Frohlich et autres, Rec. p 139. 
coming into force of the statutes or decrees "manifestly impossible" that the immediate application of the legislation will be refused ${ }^{19}$. This liberal line of case law avoids the situation arising where the government, as a result of ill will, can create obstacles to the application of a statute by indefinitely delaying the promulgation of the regulatory text necessary for its entry into operation. Thus for example, when a statute states the principle that by the government shall indemnify certain types of loss and the grant of the indemnity is made conditional on a prior examination by a special committee whose composition and procedures have to be established by a special law, the absence of that law which prevents the operation of a particular procedure does not amount to a circumstance which deprives affected parties of their right to the indemnity ${ }^{20}$.

Viewed in the light of these case law principles, there is no doubt that article 89B of the basic law of 1984 of French Polynesia was immediately applicable, and there was no need for its entry into operation to await the promulgation of a decision which established the organisation and procedures of the Councils of the Archipelagoes ${ }^{21}$. It is to be noted at the outset that this article "establishes" a Council of the Archipelago for each group of islands. And further, as far as the composition of these councils is concerned, it is to be noted that there is no necessity to add other requirements since all the essential conditions are set out in article 89B: thus the membership of the Councils is specified (Mayors and Territorial Councillors). The same observation can be made in relation to the jurisdiction of the Councils. This also is sufficiently identified: discretionary and compulsory jurisdiction; competence to request or give advice. Finally, some rules relative to the organisation of the councils and the procedures they are to follow are indicated in article 89B: annual election of the president of a Council of the Archipelago from among the members of the Council, and the role of the representative of the State and of the President of the territorial executive. There is however no other detail in the statute about the operation of these bodies ${ }^{22}$.

19 CE ass. 10 mars 1961, Union départementale des associations familiales de la Haute-Savoie, Rec. p 172; CE sect. 28 février 1969, Ministre des armées c/ Sieur Furno, Rec. p 126; CE 17 février 1971, Ministre de la santé publique et de la sécurité sociale c/ Union pharmaceutique des sociétés mutualistes de la Haute-Garonne, Rec. p 133; CE sect. 8 juin 1973, Dame Dijon et ministre des anciens combattants et victimes de guerre, A.J.D.A., 1974, p 161.

20 CE 1er mars 1957, Sieur de France, Rec. p 133.

21 This was also the view of the Commissioner of the government, $\mathrm{H}$ Lenoir - in this matter: "Article 89B was applicable in itself and ... the rules of application eventually established by the territorial assembly were not in any way a necessary precondition to the setting in place of the councils of the archipelagos".

22 It was intentional that the legislature did not go further in the definition of these rules of operation so that "the territorial assembly could, locally, provide the framework for them that is the most suitable", according to the statement of Louis Le Pense, Minister for Overseas Departments and Territories, during the debates in the National Assembly, JORF, debates, 13 June 1990, p2419. 
However, this legislative gap does not amount to a legal gap sufficient to prevent the entry into force immediately of article $89 \mathrm{~B}$ or require the prior intervention of a decision of the Territorial Assembly. In the absence of legislative provisions relating to noncontentious administrative procedure, the case law has identified a multitude of "general rules of procedure ${ }^{\prime 23}$ - some of which moreover have acquired the value of general principles of law, or even of principles of constitutional value by reason of their constitutional importance - which bind the government and thus allow consultative bodies to operate. What is more, nothing prevents the Councils of the Archipelagoes from deciding on their own internal regulation in order to settle the rules of their internal functioning.

The administrative court preferred, as a way of nullifying the decision relating to tariffs for marine transport, to consider that the provisions for article $89 \mathrm{~B}$ of the basic law were not directly applicable, perhaps in order to preserve the residual jurisdiction of the legislative body of French Polynesia which must prescribe within the legal framework set out by the basic law, the rules relating to the organisation and operation of the councils of the archipelagos. But whatever the method of annulling the tariff was adopted, this decision is pregnant with possibilities. The people of the Territory in their capacity as residents of an archipelago know that henceforth they cannot be deprived of this means of participating in government decision-making. Of course it remains possible for the government of Gaston Flosse to have the basic law amended on this point, by for example having article $89 \mathrm{~B}$ repealed ${ }^{24}$.

24 In order to do this, it would be necessary to have an organic law passed by the French Parliament. Since the amendment of article 74 of the French Constitution, in 25 June 1992, laws relating to the status of overseas territories must be in the form of organic law. This means, that the law must fulfil other requirements in addition to the normal procedures for passing of a statute. 